
С ТЕРРОРИСТИЧЕСКОЙ ДЕЯТЕЛЬНОСТЬЮ

Nechiporenko G. A.

\title{
CRIMINAL-LEGAL FEATURES OF THE CHARACTERISTICS OF CRIMES RELATED TO TERRORIST ACTIVITIES
}

К преступлениям террористической направленности (террористической деятельности) относится более двух десятков составов преступлений, предусмотренных действующим Уголовным кодексом Российской Федерации, что делает достаточно сложным проведения полного уголовно-правового анализа преступлений террористической направленности, в рамках научной статьи, более того, каждый из представленных составов, должен подвергаться исследованию путем самостоятельного уголовноправового анализа элементов состава преступления. В виду этого, в данной научной статье максимально сжаты и обобщены объективные и субъективные признаки отдельных преступлений террористической направленности, но при этом следует отметить, что не раскрыт полный их спектр в виду объективных требования, предъявляемых к научной статье.

Ключевые слова: террористическая деятельность, объективные признаки, субъективные признаки, квалификация.

Terrorist crimes (terrorist activities) include more than two dozen corpus delicti provided for by the current Criminal Code of the Russian Federation, which makes it rather difficult to conduct a full criminal analysis of terrorist crimes within the framework of a scientific article, moreover, each of the presented structures, should be investigated by means of an independent criminal-legal analysis of the elements of a crime. In view of this, in this scientific article the objective and subjective signs of individual crimes of a terrorist orientation are maximally compressed and generalized, but it should be noted that their full range is not disclosed in view of the objective requirements for a scientific article.

Keywords: terrorist activity, objective signs, subjective signs, qualifications.

Несмотря на то, что число преступлений террористической направленности в России за последние годы сократилось, вместе с тем, проблемы уголовно-правового характера преступлений, связанных с террористической деятельностью, безусловно, являются актуальными, а их исследование является обоснованным.

Так, по словам Директора ФСБ России А. Бортникова, если в 2010 г. было 778 преступлений террористической направленности, то в 2019 г. только четыре. Правоохранительным органам удалось в десятки раз снизить проявления террористической направленности в стране, прежде всего на территории Северного Кав- каза. В октябре прошлого года по официальным данным судебного департамента Верховного суда РФ сообщил, в первой половине 2019 года в России был осужден за терроризм 121 человек.

Кроме того, в 2019 г. четыре теракта было предотвращено в ЦФО и 15 - на Северном Кавказе[1].

Выявляя сложности квалификации преступлений террористической направленности, следует подчеркнуть, что данные преступления всегда посягают на основной объект - общественную безопасность. Вместе с тем, данное утверждение не является бесспорным, поскольку как показали результаты анализа различных 
мнений ученых и законодательства ряда отдельных зарубежных государств, преступления террористической направленности нередко признаются преступления, посягающие на государство (институты государственной власти), а также преступления, посягающими на мир и безопасность всего человечества.

Применительно к характеристике объективной стороны преступлений террористического характера, то, их видовое разнообразие предполагает собой практически весь спектр признаков объективной стороны конкретного состава, раскрыть которые в рамках единичного исследования представляется некорректным. Проанализировав признаки объективной стороны преступления, предусмотренного ст. 205 УК РФ будет правильным сформулировать дополнение, которым должно быть дополнено Постановление Пленума Верховного Суда РФ от 9 февраля 2012 г. № 1 «О некоторых вопросах судебной практики по уголовным делам о преступлениях террористической направленности»: «следует понимать действия, сопоставимые по последствиям со взрывом или поджогом, например устройство аварий на объектах жизнеобеспечения; разрушение транспортных коммуникаций; заражение источников питьевого водоснабжения и продуктов питания; распространение болезнетворных микробов, способных вызвать эпидемию или эпизоотию; радиоактивное, химическое, биологическое (бактериологическое) и иное заражение местности; вооруженное нападение на населенные пункты, обстрелы жилых домов, школ, больниц, административных зданий, мест дислокации (расположения) военнослужащих или сотрудников правоохранительных органов; захват и (или) разрушение зданий, вокзалов, портов, культурных или религиозных сооружений, кибератака информационно-телекомунникацинных сетей удаленного управления в сфере здравоохранения и общественной безопасности».

При рассмотрении субъективных признаков преступлений, террористической направленности, в частности Н.С. Таганцев указывает на то, что осуществление познаний явлений окружающей нас действительности, а также внутренней взаимосвязи данных явлений прямо обнаруживается не вдруг, с самим проявлением существующей умственной жизни человека и гражданина, а включая его постепенное развитие способностей осуществлять запоминание и понимание взаимоотношений, а кроме того - явлений окру- жающего мира, также и выделение из указанных явлений собственной деятельности, осуществление познания человека самим собой и своего отношения к внешнему миру, и к разумению явлений общественной и государственной жизни [1, с. 233].

Устанавливая низкий возраст уголовной ответственности за преступления, предусмотренные ст. 205, 206, 361 УК РФ, законодатель, скорее всего, учитывал высокую степень общественной опасности данных преступлений, их распространенность среди подростков, специфичность развития подростков, их способность понимать общественную значимость подобных деяний и обязанность понести наказание в случае их совершения. Так, например, на снижение возраста ответственности по ст. 205 УК РФ оказала практика, указывающая на большое количество подростков, используемых в террористических актах, в силу возраста легко попадающих под влияние взрослых и совершающих под их руководством террористические акты.

Однако именно тот факт, что подростки, совершая данные виды преступлений фактически не действуют самостоятельно, не являются инициаторами рассматриваемых преступлений, в подавляющем большинстве случаев сами являются жертвами негативного влияния взрослых преступников (неблагополучные семьи, недосмотр органов государственной власти, халатность сотрудников на места и т.д.), которые посредством различных психологических уловок и в силу прямого влияния на несформировавшуюся психику несовершеннолетнего по сути заставляют последних совершать указанные преступления. В связи с этим, стоит предложить повысить возраст ответственности по преступлениям, предусмотренным ст. 205, 206, 361 УК РФ и одновременно включить в них квалифицирующий признак, установив ответственность за совершение действий, указанных в диспозиции рассматриваемых статей, совершенные с использованием несовершеннолетних, не исключая при квалификации совокупность преступлений с ст. 150 УК РФ.

Таким образом, можно сформулировать ряд бесспорных выводов. Отечественное законодательство в сфере уголовно-правового противодействия террористическим преступлениям активно развивается, о чем свидетельствует нормотворчество последних лет: во-первых, выделить в УК РФ отдельную норму, криминализирующей оказание финансовой 
помощи терроризму - ст. 2057 «Финансирование террористической деятельности»; во-вторых, полагаю, что более верно ст. 2056 УК РФ именовать «Несообщение о террористическом преступлении».

Субъектом преступления террористической направленности могут быть в одних случаях лица, достигшие возраста 14 лет (ст. 205, 2053, 2054, 2055, 206, 207, 208, 211 УК РФ), в других случаях лица, достигшие возраста 16 лет (ст. 278, 279, 281, 295, 318 УК РФ). В связи с этим, считаю целесообразным повысить возраст ответственности по преступлениям, предусмотренным ст. 205, 206, 361 УК РФ и одновременно включить в них квалифицирующий признак, установив ответственность за совершение действий, указанных в диспозиции рассматриваемых статей, совершенные с использованием несовершеннолетних, не исключая совокупность преступлений (ст. 150 УК РФ). Касаемо субъективной стороны преступлений террористической направленности отмечу, что, по моему мнению, она всегда характеризуется прямым умыслом, при этом крайне важно установить мотив и цель - так как именно мотив и цель относят те или иные деяния к террористическим по своей сути.

Как показывает анализ, в сфере квалификации и разграничения преступлений террористической направленности существует огромное количество проблем (рассмотреть весь спектр которых в рамках одного параграфа не представляется возможным). Вместе с тем, по результату рассмотрения некоторых проблемных вопросов в данной сфере, я пришла к выводу, во-первых, о необходимости исключить из содержания ст. 361УК РФ часть вторую. При этом в определении финансирования терроризма, содержащемся в примечании 1к ст.2051 УК РФ перечень преступлений террористической направленности необходимо добавить ст. 361 УК РФ. Такая редакция указанных норм позволит избежать дискуссионных вопросов в следственно-судебной практике и будет способствовать их единообразному применению. Во-вторых, Верховный Суд РФ должен разъяснить в своих постановлениях ряд важных вопросов, касающихся применения ст. 2051, 280 и 2801 УК РФ.

\section{Литература}

1. ФСБ назвала число преступлений террористической направленности в 2019 году [Электронный ресурc] URL:https://iz.ru/1024208/2020-06-16/v-fsb-nazvalichislo-prestuplenii-terroristicheskoi-napravlennosti-v-2019-godu(дата обращения: 27 ноября 2020)

2.Таганцев Н.С. Лекции по русскому уголовному праву. Часть особенная / Н.С. Таганцев. - Спб.: Типография С-Петербургской городской тюрьмы, 1894. - 394 с.

\section{References}

1. FSB nazvala chislo prestupleniy terroristicheskoy napravlennosti $v 2019$ godu [Elektronnyy resurs] URL:https://iz.ru/1024208/2020-06-16/v-fsb-nazvali-chisloprestuplenii-terroristicheskoi-napravlennosti-v-2019-godu(data obrashcheniya: 27 noyabrya 2020)

2. Tagantsev N.S. Lektsii po russkomu ugolovnomu pravu. Chast' osobennaya / N.S. Tagantsev. - Spb.: Tipografiya S-Peterburgskoy gorodskoy tyur'my, 1894. - $394 \mathrm{~s}$.

НЕЧИПОРЕНКО Геннадий Анатольевич, заместитель руководителя аппарата оперативного штаба в Челябинской области. 454091, г. Челябинск, ул. Коммуны, д.70. E-mail: nga@mail.ru

NECHIPORENKO Gennady Anatolyevich, deputy chief of staff of the operational headquarters in the Chelyabinsk region. 454091, Chelyabinsk, ul. Commune, d.70. E-mail: nga@mail.ru 